\title{
OCCURRENCE OF GASTROLITHS IN SOUTH AMERICAN SEA LIONS (OTARIA BYRONIA) FROM SOUTHERN BRAZIL
}

\author{
César Jaeger Drehmer ${ }^{1,2}$ and Larissa Rosa de Oliveira ${ }^{3,4,5}$
}

Gastroliths are stones present in the stomach of many vertebrate species and their occurrence in fossil and living vertebrates is well documented in the scientific literature. Vertebrate groups, especially aquatic tetrapods, including Crocodilia, Spheniscidae, Mysticeti, Odontoceti and Pinnipedia, and the extinct Plesiosauria are examples of such occurrence (for a complete review see Taylor, 1993).

Although there is a paucity of detailed information about gastroliths in individual species of pinnipeds, there are records of their occurrence in species in all three families (Phocidae, Odobenidae and Otariidae, Taylor, 1993). In otariids, gastroliths have been described in Zalophus californianus (Scheffer and Neff, 1948), Neophoca cinerea, Phocarctos hookeri and Arctocephalus pusillus (Marlow, 1975), Eumetopias jubatus (Fiscus and Baines, 1966) and Callorhinus ursinus (Taylor, 1993). In the case of the South American sea lion, Otaria byronia (Pinnipedia, Otariidae) occurrence of gastroliths was first reported in 1934 (Hamilton,
1934), and more recently by Vaz-Ferreira (1981). Here we report the presence of gastroliths in seven specimens of South American sea lions collected on the southern coast of Brazil. We also present measurements and weight of the gastroliths (individual and total) from each specimen (see Table 1). The occurrence of gastroliths in the stomach contents of Pinnipedia has been identified as an important aspect of their biology (Riedman, 1990). However, no mention is made of gastroliths in recent textbooks on marine mammals (e.g. Berta and Sumich, 1999; Perrin et al., 2001) the word 'gastrolith' appearing in neither the glossary nor the remissive index.

In total 47 specimens of Otaria byronia were collected during beach surveys along the coast of Rio Grande do Sul State (between $30^{\circ}$ and $31^{\circ}$ South), between 1990 and 1998. Skulls and gastroliths from specimens are deposited in Mammal Collection at Museu de Ciências Naturais (MCN), Fundação Zoobotânica do Rio Grande do Sul, Porto Alegre, Brazil. Condylo-basal length (CBL)

Table 1. Information about specimens of South American seal lions and the gastroliths found in their stomachs. Condylo-basal length (CBL) expressed in millimeters and suture-age (S.A.) according to Sivertsen's Method.

\begin{tabular}{|c|c|c|c|c|c|c|}
\hline SPECIMEN & CBL & S.A. & $\begin{array}{c}\mathrm{N} \text { OF } \\
\text { GASTROLITHS } \\
\end{array}$ & $\begin{array}{l}\text { INDIVIDUAL WEIGHTS } \\
(\mathrm{g})\end{array}$ & $\begin{array}{c}\text { MAXIMUM THICKNESS } \\
(\mathrm{cm})\end{array}$ & $\begin{array}{c}\text { TOTAL WEIGHT } \\
(\mathrm{g})\end{array}$ \\
\hline \multirow[t]{2}{*}{2459} & 329.6 & 25 & 2 & 44.02 & 2.06 & \\
\hline & & & & 359.45 & 3.82 & 403.47 \\
\hline \multirow[t]{2}{*}{2460} & 338.4 & 30 & 2 & 302.64 & 3.05 & \\
\hline & & & & 641.60 & 3.92 & 944.24 \\
\hline \multirow[t]{2}{*}{2462} & 268.4 & 36 & 2 & 301.36 & 4.39 & \\
\hline & & & & 348.90 & 6.00 & 650.26 \\
\hline 2602 & 284.2 & 15 & 1 & 200.23 & 2.80 & 200.23 \\
\hline \multirow[t]{2}{*}{2629} & 348.9 & 34 & 2 & 186.73 & 3.65 & \\
\hline & & & & 243.86 & 2.70 & 430.59 \\
\hline \multirow[t]{2}{*}{2807} & 341.1 & 35 & 2 & 85.10 & 2.45 & \\
\hline & & & & 160.20 & 2.95 & 245.30 \\
\hline 2832 & 345.3 & 36 & 1 & 720.00 & 5.10 & 720.00 \\
\hline
\end{tabular}

\footnotetext{
${ }^{1}$ Universidade Federal de Pelotas, Campus Universitário s/no. Depto. Zoologia \& Genética, Caixa Postal 354, Pelotas, RS, 96010-900, Brazil. E-mail: cjaeger@terra.com.br.

${ }^{2}$ Programa de Pós-Graduação em Biologia Animal, Universidade Federal do Rio Grande do Sul, Depto. de Zoologia. Av. Bento Gonçalves, 9500, Bloco IV, Prédio 43435, Sala 123, Porto Alegre, RS, 91.540-000, Brazil.

${ }^{3}$ Grupo de Estudos de Mamíferos Aquáticos do Rio Grande do Sul (GEMARS). Rua Felipe Neri, 382/203, Porto Alegre, RS, 90440-150, Brazil.

${ }^{4}$ Centro de Estudos Costeiros, Limnológicos e Marinhos (CECLIMAR) and Universidade Federal do Rio Grande do Sul (UFRGS). Av. Tramandaí, 976, Imbé, RS, 95625-000, Brazil.

${ }^{5}$ Laboratório de Biologia Evolutiva e Conservação de Vertebrados, Instituto de Biociências, Universidade de São Paulo (USP), Rua do Matão 277, Cidade Universitária, São Paulo, SP, 05508-090, Brazil.

E-mail: lari@ib.usp.br.

${ }^{6}$ Crespo, E.A., Nepomnaschy, P. and Garcia, N. (1990) Analisis preliminar de la dieta de mamiferos marinos sobre la base de contenidos estomacales y fecas. Page 70 in Resúmenes, IV Reunión de Trabajo de Especialistas em Mamíferos Acuáticos de América del Sur, 12-15 November, Valdivia, Chile. Oliveira, L.R. and Ott, P.H. (1996) Estudo sobre a alimentação dos pinípedes ocorrentes no litoral norte do Rio Grande do Sul, sul do Brasil. Page 44 in Resúmenes, VII Reunión de Trabajo de Especialistas em Mamíferos Acuáticos de América del Sur, 22-25 October, Viña del Mar, Chile.
} 
expressed in millimeters and suture-age (S.A.) according Sivertsen's method (Sivertsen, 1954) for each specimen are presented in Table 1 . No records of total length of the specimens are available. Stomach content analysis information was available for only seven individuals. None of these seven specimens presented food or parasites in the stomach. However it is not known whether the collectors performed a detailed analysis, or collected gastroliths, rejecting other stomach contents.

Gastroliths reported here are in general of irregular shape, but the pebbles are flat (Figure 2B, 3), slightly flat (Figure 2A) or roundish (Figure 1B). Also gastroliths are smooth (Figure 3 ) or rough (Figure 4,5 ). We suggest that the combination of roundish shape and smooth surface will facilitate the act of swallowing. Five hypotheses have been proposed to explain the presence and/or probable function of gastroliths (Riedman, 1990; Taylor, 1993) in pinnipeds: 1) gastroliths could be incidentally consumed during foraging; 2 ) to alleviate hunger during fasting periods; 3 ) to grind food acting as bird gizzard; 4) to crush parasites which infest their stomachs; and 5) to control buoyancy during foraging dives. The last hypothesis has been favored (Taylor, 1993) and related to underwater flight, specifically in the case of plesiosaurs, penguins and otariids, which chiefly use forelimbs for swimming. Koen Alonso et al. (2000) analysed the stomach contents of South American sea lions from Argentine waters and corroborated the buoyancy control hypothesis. Koen Alonso et al. (2000) demonstrated that gastroliths are unrelated to parasite infestation but that gastrolith weight was positively correlated to the length of individual sea lions, suggesting their use as ballast for buoyancy regulation. No further information on the characteristics of the gastroliths was provided. The buoyancy control hypothesis could be strengthened by the benthic foraging behavior previously described for individuals collected along the species range (George-Nascimento et al., 1985; Crespo et al., 19906; Oliveira and Ott, 19967). Although the sample size of our analysis is small, information presented in Table 1 suggests some correlation between total gastrolith weight and the CBL of individual sea lions. Evidence from a greater number of samples may provide to support the application in Brazil, of the hypothesis formulated for Argentina by Koen Alonso et al. (2000).
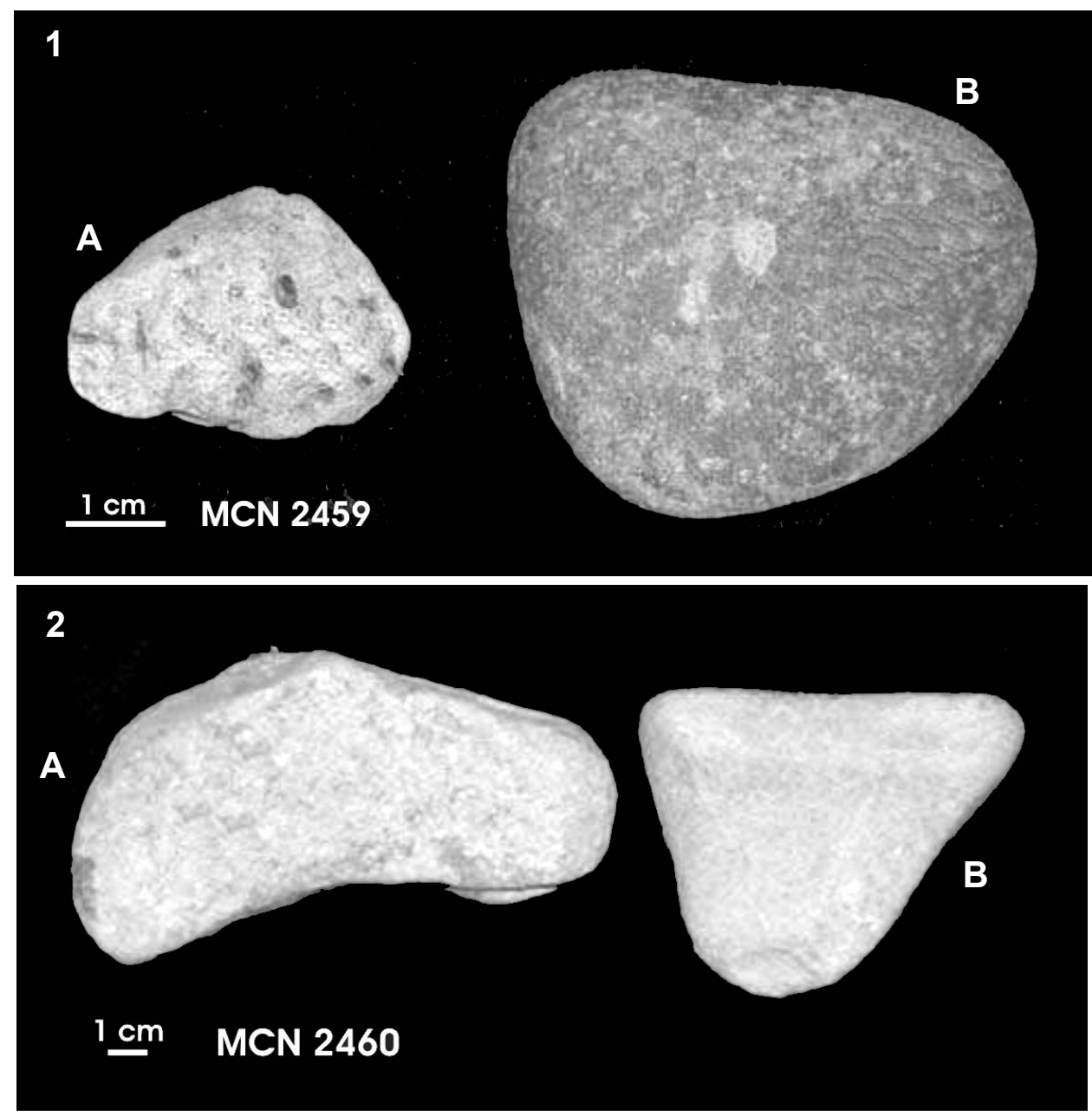

Gastroliths from Otaria byronia specimens: figure 1. MCN 2459; figure 2. MCN 2460 

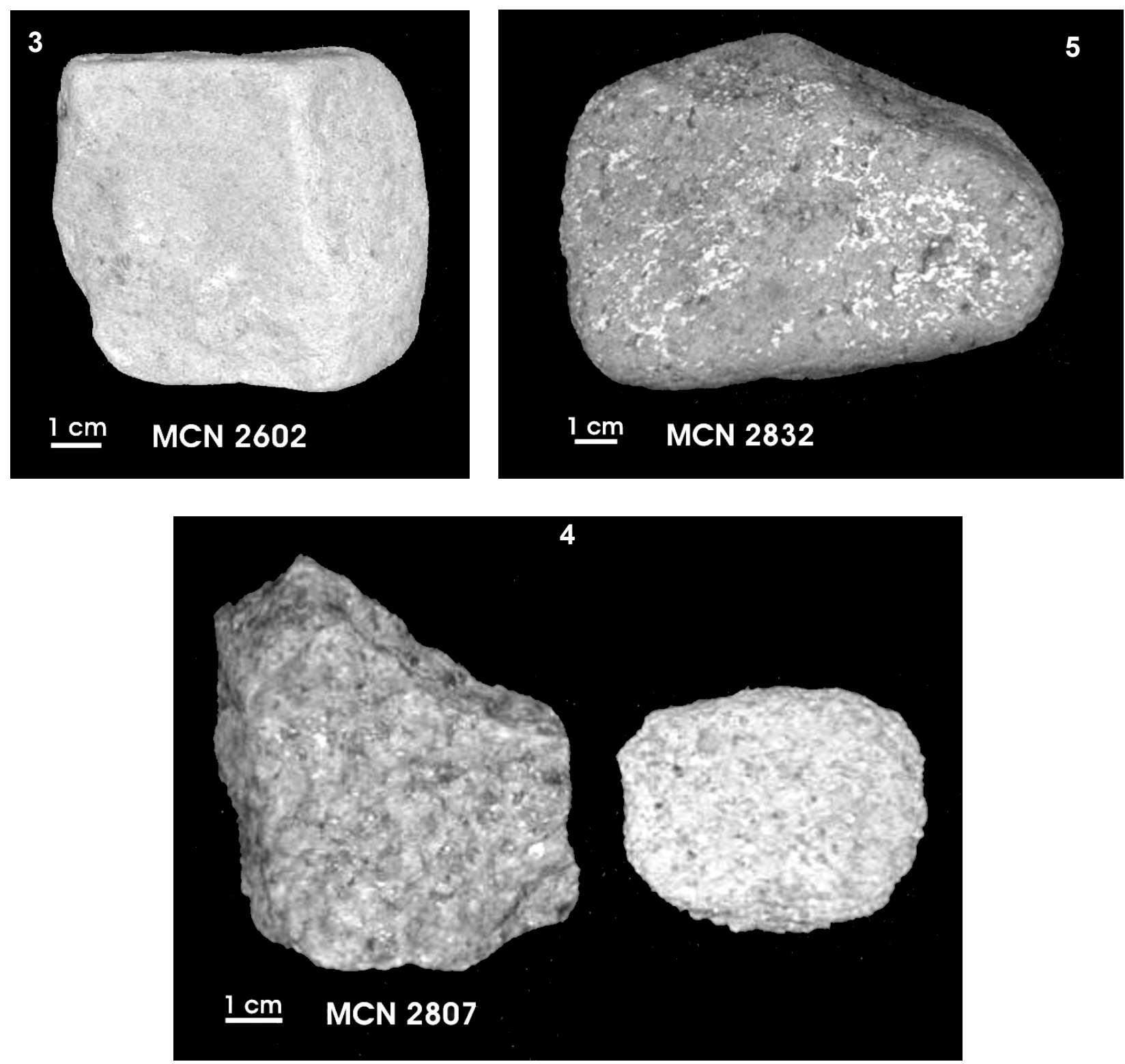

Gastroliths from Otaria byronia specimens: figure 3. MCN 2602; figure 4. MCN 2807; figure 5. MCN 2832.

\section{Acknowledgments}

We thank Jorge Ferigolo, Eduardo Borsato and Daniela Sanfelice for collecting the analysed material. Mônica Muelbert, James Holborow and an anonymous referee provided useful comments to this note. We also thank Flávio Calippo for helping with the pictures' layout.

\section{References}

Berta, A. and Sumich, J.L. (1999) Marine Mammals - Evolutionary Biology. Academic Press, San Diego.

Fiscus, C.H. and Baines, G.A. (1966) Food and feeding behavior of Steller and California Sea Lions. Journal of Mammalogy 47: 195-200. George-Nascimento, M., Bustamante, R. and Oyarzum, C. (1985) Feeding ecology of the South American sea lion Otaria flavescens: food contents and food selectivity. Marine Ecology Progress Series 21: 135-143.

Hamilton, J.E. (1934) The Southern Sea Lion Otaria byronia (de Blainville, 1820). Discovery Reports 8: 269-318.

Koen Alonso, M., Crespo, E.A., Pedraza, S.N., García, N.A. and Coscarella, M.A. (2000) Food habits of the South American sea lion, Otaria flavescens, off Patagonia, Argentina. Fishery Bulletin 98: 250-263.

Marlow, B.J. (1975) The comparative behaviour of the Australasian sea lions Neophoca cinerea and Phocarctos hookeri (Pinnipedia, Otariidae). Mammalia 39: 159-230.

Perrin, W.F., Würsig, B and Thewissen, J.G.M. (Eds) (2002) Encyclopedia of Marine Mammals. Academic Press, San Diego.

Riedman, M. (1990) The Pinnipeds. Seals, Sea Lions, and Walruses. University of California, Berkeley.

Scheffer, V.B. and Neff, J.A. (1948) Food of California sea lions. Journal of Mammalogy 29(1): 67-68. 
Sivertsen, E. (1954) A survey on the eared seals (family Otariidae) with remarks on the Antarctic seals collected by $M / K$ "Norvegia" in 1928-1929. Scientific Results of the Norwegian Antarctic Expeditions, 36. Det Norske Vidskaps Akademi I Oslo.

Taylor, M.A. (1993) Stomach stones for feeding or buoyancy? The occurrence and function of gastroliths in marine tetrapods. Philosophical Transactions of the Royal Society of London B 341: 163-175.

Vaz-Ferreira, R. (1981) South American Sea Lion Otaria flavescens (Shaw, 1800). Pages 39-65 in Ridgway, S.H. and Harrison, R.J. (Eds) Handbook of Marine Mammals, vol. 2, Seals. Academis Press. London. 